\title{
Structure and function of glycosphingolipids on small extracellular vesicles
}

\author{
Xin $\mathrm{He}^{1} \cdot$ Feng Guan ${ }^{1} \cdot$ Lei Lei $^{1}$ (D)
}

Received: 23 December 2021 / Revised: 12 February 2022 / Accepted: 16 February 2022 / Published online: 24 February 2022

(c) The Author(s), under exclusive licence to Springer Science+Business Media, LLC, part of Springer Nature 2022

\begin{abstract}
Extracellular vesicles (EVs) are membrane-delineated particles secreted by most types of cells under both normal and pathophysiological conditions. EVs are believed to mediate intercellular communication by serving as carriers of different bioactive ingredients, including proteins, nucleic acids and lipids. Glycoconjugates are complex molecules consisting of covalently linked carbohydrate with proteins or lipids. These glycoconjugates play essential roles in the sorting of vesicular protein and the uptake of small extracellular vesicles (30-100 nm, sEVs) into recipient cells. Glycosphingolipids (GSLs), one subtype of glycolipids, which are ubiquitous membrane components in almost all living organisms, are also commonly distributed on sEVs. However, the study of functional roles of GSLs on sEVs are far behind than other functional cargos. The purpose of this review is to highlight the importance of GSLs on sEVs. Initially, we described classification and structure of GSLs. Then, we briefly introduced the essential functions of GSLs, which are able to interact with functional membrane proteins, such as growth factor receptors, integrins and tetraspanins, to modulate cell growth, adhesion and cell motility. In addition, we discussed analytical methods for studying GSLs on sEVs. Finally, we focused on the function of GSLs on sEVs, including regulating the aggregation of extracellular $\alpha$-synuclein ( $\alpha$-syn) or extracellular amyloid- $\beta$ (A $\beta$ ) and influencing tumor cell malignancy.
\end{abstract}

Keywords Glycoconjugate $\cdot$ Glycosphingolipids $\cdot$ Small extracellular vesicles $\cdot \alpha$-Synuclein $\cdot$ Amyloid- $\beta$

$\begin{array}{ll}\text { Abbreviations } \\ \text { sEVs } & \text { Small extracellular vesicles } \\ \text { GSLs } & \text { Glycosphingolipids } \\ \text { GalCer } & \text { Galactose-Ceramide } \\ \text { GlcCer } & \text { Glucose-Ceramide } \\ \text { GFRs } & \text { Growth factor receptors } \\ \text { EGFR } & \text { Epidermal growth factor receptor } \\ \text { FGFR } & \text { Fibroblast growth factor receptor } \\ \text { PDGFR } & \text { Platelet derived growth factor receptor } \\ \text { CPI } & \text { Carbohydrate-to-protein } \\ \text { CCI } & \text { Carbohydrate-to-carbohydrate interaction } \\ \text { Gal-3 } & \text { Galectin-3 }\end{array}$

Feng Guan

guanfeng@nwu.edu.cn

Lei Lei

leilei@nwu.edu.cn

1 Key Laboratory of Resource Biology and Biotechnology in Western China, Ministry of Education, Provincial Key Laboratory of Biotechnology, College of Life Sciences, Northwest University, Xi' an, China

$\begin{array}{ll}\text { ESI-IT-MS } & \begin{array}{l}\text { Electrospray ionization ion trap mass } \\ \text { spectrometry }\end{array} \\ \text { LC-MS } & \text { Liquid chromatograph- } \\ \text { TLC } & \text { Thin layer chromatography } \\ \text { CTB } & \text { Cholera toxin B subunit } \\ \text { PD } & \text { Parkinson disease } \\ \text { AD } & \text { Alzheimer disease } \\ \alpha-\text { syn } & \alpha \text {-Synuclein } \\ \text { S1P1R } & \text { Sphingosine 1-phosphate receptor 1 } \\ \text { Gi } & \text { Inhibitory G-protein } \\ \text { A } \beta & \text { Amyloid- } \beta \\ \text { Ga } \beta & \text { GM1-bound A } \beta\end{array}$

\section{Introduction}

Extracellular vesicles (EVs) are membrane-delineated particles secreted by most types of cells and are present in all body fluids under both normal and pathophysiological conditions [1]. Although the study of EVs is constantly increased, the subtypes of EVs remain less well-defined. Basically, EVs are classified as exosomes, microvesicles, and apoptotic bodies. 
Exosomes are ranging from $40-120 \mathrm{~nm}$, microvesicles are $50-1000 \mathrm{~nm}$ and apoptotic bodies are 500-2000 nm in diameter [1]. And the term "small extracellular vesicles" (sEVs) refers to a heterogeneous population of EVs less than $200 \mathrm{~nm}$ in diameter.

sEVs have been conspicuously recognized for their role in mediating intercellular communication by serving as carriers of different bioactive ingredients, including proteins, RNAs(miRNA, long non-coding RNA and others)and lipids from donor cells to surrounding and distant recipient cells [2]. Recently, many studies have revealed that SEVs derived from tumor cells play critical roles in key progressions associated with tumor development and metastasis [3, 4].

Similar to cell membrane, sEVs are heavily covered by glycoconjugates, which are shown in Fig. 1 [5]. Glycoconjugates are complex molecules consisting of covalently linked carbohydrate with proteins or lipids. The glycoconjugates on which carbohydrates linked protein are termed either glycoproteins or proteoglycans. Glycoproteins are proteins which contain carbohydrates covalently attached to amino acids, usually by nitrogen or oxygen linkages, also known as $\mathrm{N}$-glycosylation and $\mathrm{O}$-glycosylation, respectively. Compared to glycoproteins, proteoglycans have a very high carbohydrate content, which are covalently linked to small polypeptides. The conjugates in which saccharides covalently attached to lipids are glycolipids [6]. These glycoconjugates play essential roles in the sorting of vesicular protein and the uptake of sEVs into recipient cells [7-10]. For example, high level of bisecting GlcNAc modification, one specific N-Glycan structure, significantly diminished the pro-metastatic functions of sEVs derived from breast cancer cells [7].

Glycosphingolipids (GSLs) are the major subclass of glycolipids, which are ubiquitous membrane components in almost all living organisms, and also commonly distributed on SEVs [11-14]. However, the study of functional roles of GSLs on sEVs are far behind than those of proteins, nucleic acids and other functional cargos. In this review, we briefly introduced the background of GSLs, and summarized the studies of GSLs on sEVs.

\section{Classification and structure of GSLs}

GSLs are classified as neutral and acidic. The former does not contain sialic acid and is frequently called cerebroside. The latter could be further divided into two subgroups, sulfatide and ganglioside. The amount of sialic acids in sulfatide is less than in gangliosides [11]. The core structure of GSLs includes the glucose-ceramide (GlcCer) or the
Fig. 1 The related-structures of $\mathrm{N}$-glycan, O-glycan, gangliosides and other glycans on sEVs

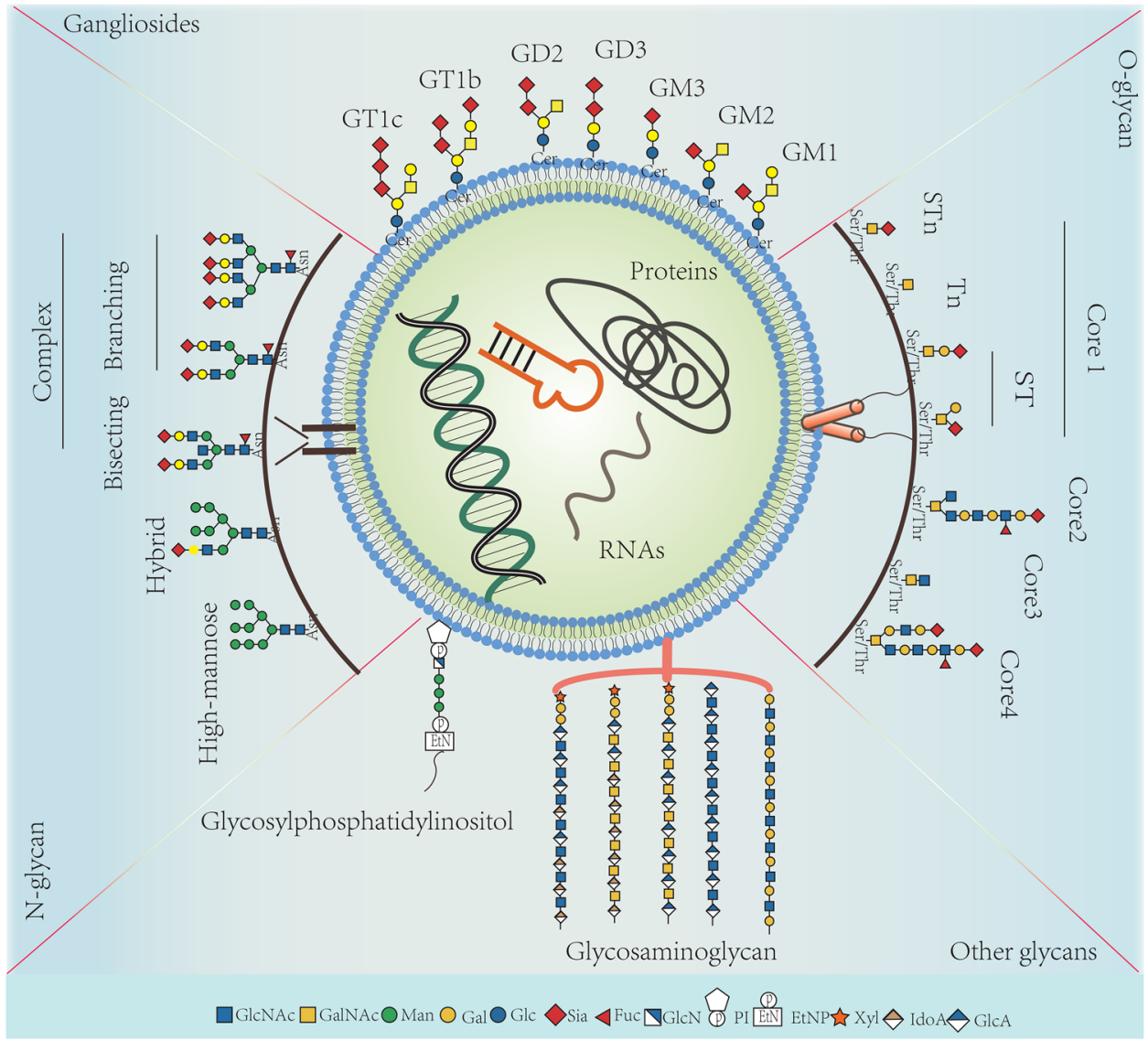


galactose-ceramide (GalCer). Furthermore, GlcCer is generally classified as globo-series, lacto-series and ganglioseries (a-series, b-series, c-series, o-series). The categories of globo-series and lacto-series are related to the covalent bond between $\mathrm{Gal}$ and $\mathrm{Gal} \beta 4 \mathrm{Glc} \beta \mathrm{Cer}$. The ganglio-series is related to the number of sialic acids. The main structures and synthesized processes of GSLs have been summarized and discussed by Professor S. Hakomori and other scientists in several reviews (Table 1) [15-18], and will not be discussed in detail here.

\section{The essential functions of GSLs}

GSLs at the cell surface membrane are able to interact with functional membrane proteins, such as growth factor receptors (GFRs), integrins and tetraspanins, to modulate cell growth, cell adhesion, and cell motility [15, 19]. It is well known that the GFRs, which include epidermal growth factor receptor (EGFR), fibroblast growth factor receptor (FGFR) and platelet derived growth factor receptor (PDGFR), is related to cell growth and cancer progression. In epidermoid carcinoma A431 cells, exogenous GM3 inhibited autophosphorylation of EGFR [20]. The possible mechanism is that GM3 inhibits EGFR tyrosine kinase by binding to GlcNAc residues of N-glycans on EGFR, which is required for EGFR function [21]. And the order of relative binding of gangliosides with EGFR was as follows: GM3 > > GM2, GD3, GM4 > GM1, GD1a, GD1b, GT1b, GD2, GQ1b > lactosylceramide [22]. In human lung embryonal fibroblast WI38, GM3 interacts specifically with FGFR, which is closely associated with c-Src, to inhibit tyrosine kinase [23]. In addition, GM1, GD1a and GT1b had stronger inhibitory effects on PDGF in mouse Swiss 3T3 cells [24].

GSLs affect cell adhesion in two ways: carbohydrate-toprotein interaction (CPI) and carbohydrate-to-carbohydrate interaction (CCI) [25]. In CPI way, GSLs could bind to a carbohydrate-binding protein, galectin-3 (Gal-3) [26]. High concentration of Gal-3 could downregulate cellular adhesion to the extracellular matrix proteins [27]. GSLs could

Table 1 The major structures of GSLs

\begin{tabular}{|c|c|c|c|c|}
\hline \multicolumn{5}{|c|}{ GalCer } \\
\hline Di-Gal core: Gal-GalCer & & Sulfatide: $\mathrm{HSO}_{3}-\mathrm{GalCer}$ & & GM4: SA-GalCer \\
\hline \multicolumn{5}{|c|}{ GlcCer } \\
\hline Globo-series & & Lacto-series & & Ganglio-series \\
\hline \multirow{4}{*}{$\begin{array}{l}\text { Gb3: Gala4-Gal-GlcCer } \\
\text { Gb4: GalNAc-Gala4-Gal-GlcCer } \\
\text { Forssman: GalNAc-GalNAc-Gal-Gal-GlcCer } \\
\text { Gb5: Gal-GalNAc-Gal-Gal-GlcCer } \\
\text { globo-H: Fuc-Gal-GalNAc-Gal-Gal-GlcCer } \\
\text { monosialyl-Gb5: SA-Gal-GalNAc-Gal-Gal-GlcCer } \\
\text { disialyl-Gb5: SA-Gal-GalNAc-Gal-Gal-GlcCer } \\
\text { iso-Gb3: Gala3-Gal-GlcCer } \\
\text { iso-Gb4: GalNAc-Gala3-Gal-GlcCer }\end{array}$} & \multirow[t]{2}{*}{ type1 } & \multirow{2}{*}{ 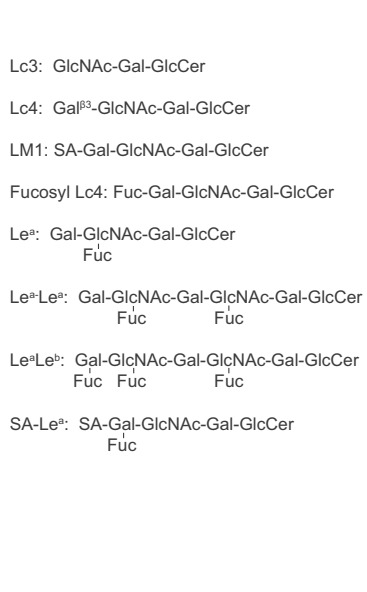 } & a-series & 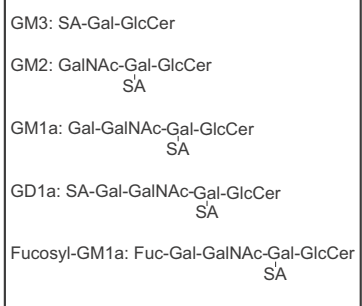 \\
\hline & & & b-series & $\begin{array}{c}\text { GD3: SA-SA-Gal-GlcCer } \\
\text { GD2: GalNAc-GalGIcCer } \\
\text { SA } \\
\text { SA } \\
\text { GD1b: Gal-GalNAc-Gal-GIcCer } \\
\text { SAA } \\
\text { SA } \\
\text { GT1b: SA-Gal-GalNAc-Gal-GlcCer } \\
\text { SA } \\
\text { SA }\end{array}$ \\
\hline & \multirow[t]{2}{*}{ type2 } & \multirow{2}{*}{ 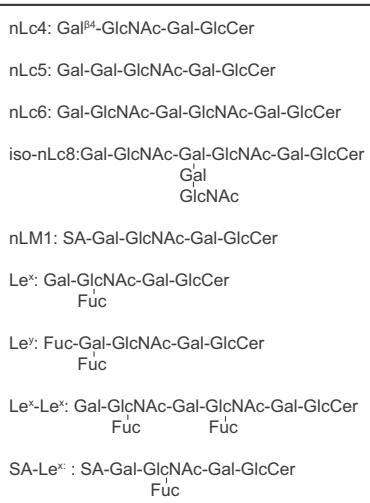 } & c-series & $\begin{array}{l}\text { GT3: SA-SA-SA-Gal-GlcCer } \\
\text { GT2: GalNAc-Gal-GIICer } \\
\text { SA } \\
\text { SA } \\
\text { SA } \\
\text { GT1c: Gal-GalNAc-Gal-GIcCer } \\
\text { SAA } \\
\text { SAA } \\
\text { SA } \\
\text { GQ1c: SA-Gal-GalNAc-Gal-GIcCer } \\
\text { SA } \\
\text { SA } \\
\text { SA }\end{array}$ \\
\hline & & & o-series & $\begin{array}{l}\text { Gg3 : GalNAc-Gal-GlcCer } \\
\text { Gg4 : Gal-GalNAc-Gal-GIcCer } \\
\text { GM1b: SA-Gal-GalNAc-Gal-GIcCer } \\
\text { GD1c: SA-SA-Gal-GalNAc-Gal-GlcCer }\end{array}$ \\
\hline
\end{tabular}


also bind to E-selectin and support E-selectin-mediated tethering and rolling [28, 29]. The lacto-series structure, sialyl-Le ${ }^{\mathrm{x}}$, has been regarded as the essential epitope for E-selectin-dependent adhesion [17]. In CCI way, GSLs on cell membranes may interact side-by-side (cis-interaction) or interact through their carbohydrate heads between two interfacing membranes (trans-interaction). Both cis- and transinteraction display proper specificity and affinity required for cell adhesion. And the characteristic feature of $\mathrm{CCI}$ is that it relies on bivalent cations in the adhesion process, particularly $\mathrm{Ca}^{2+}[17] . \mathrm{Ca}^{2+}$ may lock the glycoside residues in an optimal configuration, or they may link the hydroxyl groups of adjacent molecules to enhance the adhesion force [30].

The complex of GSLs and tetraspanins could regulate cell motility by inhibiting integrin receptors [30]. The complex exists on the special membrane microdomain: glycosynapse [31]. The function of integrin, including $\alpha$-subunit and $\beta$-subunit, is affected by $\mathrm{N}$-glycosylation and by interaction with GSLs or tetraspanins [32]. GM3 and GM2 are the most well studied GSLs in the glycosynapse. The complex of GM3 and CD9 interacts with integrin $\alpha 3$ were demonstrated by confocal microscopy, and the complex was able to inhibit cell motility by regulating laminin-5 [33]. Moreover, the formation of GM3/CD9/ $\alpha 5 \beta 1$ complex inhibited motility and invasiveness in chicken and mouse fibroblasts by reversion of the Juninduced oncogenic phenotype [34]. Hakomori and coworkers also demonstrated that the complex of GM2 and CD82 interacted with c-Met, which inhibited the interaction between integrin $\alpha 3 \beta 1$ and c-Met, whereby c-Met tyrosine phosphorylation was suppressed and cell invasiveness was inhibited [35].

GSLs are also associated with malignant properties of tumor. Glucosylceramide synthase (GCS) is the rate-limiting enzyme in the GSL-biosynthesis pathway and overexpressed in hepatocellular, breast, cervix and non-small cell lung cancer [36]. In colorectal cancer, Gb3 promotes cell invasiveness and tumor growth [37]. Exogenous Gb4 activates EGFR and induces the ERK pathway [38]. Gb5 promotes proliferation in vivo [39]. GM1 and GD1a are closely related to anticancer effects of anti-EpCAM mAb, treatment of which significantly inhibited the growth of colon tumors [40]. In breast cancer, globo-H promotes cell invasion and reduces apoptosis [41]. GD3 promotes metastasis in vivo [42]. GM2 higher expression is associated with breast cancer cell stemness [43]. In Leukemia, Lc3, GM3 and nLc4 upregulate in patients' bone marrow, and are possibly involved in initiation and differentiation of acute myeloid leukemia [44]. GD2 is overexpressed in neuroectoderm-derived tumors and is considered as a marker in melanoma, glioblastoma and neuroblastoma [45]. It was first identified as a target for immunotherapy, and dinutuximab was an FDA-approved anti-GD2 monoclonal antibody for the treatment of neuroblastoma [46]. Therefore, GSLs as targets for immunotherapy could expand the range of anticancer pharmaceutical targets.
GSLs change in central nervous system with aging and neurodegenerative diseases, including Parkinson disease (PD), Alzheimer's disease (AD). In the aging human brain and PD, levels of GlcCer, lactosylceramide and GM1a are elevated, while levels of GD1a, GD1b and GT1b are decreased [47]. AD model mice could be generated in the genetic background of GD3 synthase knockout [48], or GM2 synthase knockout [49]. The abnormal aggregation of amyloid- $\beta$ peptide $(\mathrm{A} \beta$ ) has been considered an important risk factor for $\mathrm{AD}$, which would induce the death of neurons. Previous articles reported that GM1-bound A $\beta(G A \beta)$ serves as the endogenous seed for the assembly of amyloid fibrils, which continuously promotes the accumulation of $A \beta$ to form insoluble protein plaques [50, 51]. However, there are also evidence showed that GM1 exhibited neuroprotective and neurorestorative effects [52-55]. In physiological level of GM1 (2-4 mol\%), A $\beta$ binding to GM1 does not cause aggregation of $\mathrm{A} \beta 40$ monomers, whereas high density GM1 (>20 mol\%) facilitates fibril formation [53]. Thus, the perturbation of GSL metabolism in the aging brain may affect neurodegenerative disorders.

\section{Identification of GSLs on sEVs}

The leading technology to identify gangliosides is Lipidmics. The Electrospray ionization ion trap mass spectrometry (ESI-IT-MS) and the liquid chromatograph-mass spectrometer (LC-MS) are also widely used [56-58]. In addition, thin layer chromatography (TLC) is commonly applied for the detection of gangliosides on sEVs $[59,60]$. Using specific GSLs' antibodies or high affinity substrates were able to effectively identify the specific gangliosides on the sEVs, including GM3, GM2, GM1, GD3 and GT1b [12, 61-63]. Cholera Toxin B (CTB), which is ligand for GM1, was expected to be incorporated in sEVs. Previous studies have confirmed that SEVs of mesenchymal stem cell were derived from the endocytosis at the lipid rafts of plasma membrane and the inhibition of sphingomyelinases reduced CTBbinding sEVs, indicating that GM1 was enriched in SEVs [64]. Furthermore, the lipidomes of the metastatic prostate cancer cell line, PC-3, and their released SEVs were analyzed by shotgun analysis on MS. This analysis revealed that hexosylceramides and GSLs (Gb3, GD1, GM1-3) in sEVs were much higher than in PC-3 cells [57]. sEVs isolated from a panel of human neuroblastoma cell lines (HTLA-230, IMR32, SH-SY5Y and GILI-N) and sEVs isolated from healthy blood cells were analyzed by cytofluorimetric assay. The result indicated that GD2 was detected in SEVs derived from all neuroblastoma cell lines but not from normal blood cells [65]. According to ExoCarta, which is a manually curated Web-based compendium of exosomal proteins, RNAs and lipids, sEVs membranes contain GSLs, including GD3, 
GM1, GM3, GT1b and GT1c [66]. In addition, GSLs are located at the outer leaflet of membrane and are easily detected by antibodies, which could be novel potential biomarkers of sEVs [57, 67].

\section{The function of GSLs on sEVs}

sEVs are circulating structures in body fluids, such as blood and urine, and involve in intercellular communication [1]. Thus, GSLs on sEVs may release in the extracellular matrix and partition into different cells and tissues. When GSLs remodeled in disease states, sEVs were able to transfer different biological information through the altered GSLs. Increasing numbers of studies have supported that GSLs on sEVs play critical roles in diseases, including PD, $\mathrm{AD}$ and cancer (Fig. 2).

GM1 and GM3 on sEVs from neuroblastoma cells have been verified to accumulate extracellular $\alpha$-Synuclein $(\alpha-$-syn) [68]. The aggregated $\alpha$-syn formed fibrils, which is the most crucial cause of neurodegeneration in PD [69]. The extracellular $\alpha$-syn also targets the gangliosides on recipient cells to drive the sphingosine 1-phosphate receptor subtype1 (S1P1R) out of the lipid rafts, resulting in the uncoupling of S1P1R from inhibitory G-protein (Gi) [70]. Subsequently, the blocked Gi signal inhibits exosomal cargo release (including $\alpha$-Syn), which may increase the cellular content of $\alpha$-syn and facilitate the aggregation of $\alpha$-syn to promote the development of PD.

The recent evidences implicated that GM1 on sEVs could promote the fibrillation of $\mathrm{A} \beta$ by facilitating its conformational transition $[71,72]$. When CTB (a specific GM1 binding ligand) or 4396C (a specific antibody to GA $\beta$ ) was used to block GM1 on sEVs, the extracellular $A \beta$ assembly was strongly reduced, indicating that GM1 may induce $A \beta$ fibril formation on the surface of sEVs [14, 73]. Interestingly, when neuron-derived sEVs were internalized by microglia, sEVs may play roles in the uptake of $\mathrm{A} \beta$ amyloid by microglia, aiding $A \beta$ degradation. This suppression was only related to oligomeric $A \beta$, but not related to sEVs-mediated $\mathrm{A} \beta$ fibrils [73]. In addition, through antibody-array based surface plasmon resonance imaging assay, GM1 was found to be more abundant on the membrane of CD171-positive sEVs [62]. CD171 is one of the most commonly used neuronal markers for SEVs, and CD171-containing sEVs could devote to the investigation of AD and PD [74, 75]. Furthermore, CD171 positive sEVs were able to stimulate the motility, proliferation, and invasiveness of glioblastoma cells [76].

Acidosis is a fundamental feature of the tumor microenvironment, which could increase tumor cell invasion, proliferation and drug resistance [77]. Low $\mathrm{pH}$ microenvironment also plays an important role in regulating the release of sEVs and the uptake of cancer cells [78]. Acidic sEVs, which GM3 were more enriched in, are intrinsically
Fig. 2 The major functions of specific GSLs GM1, GM3 and GD3 on sEVs

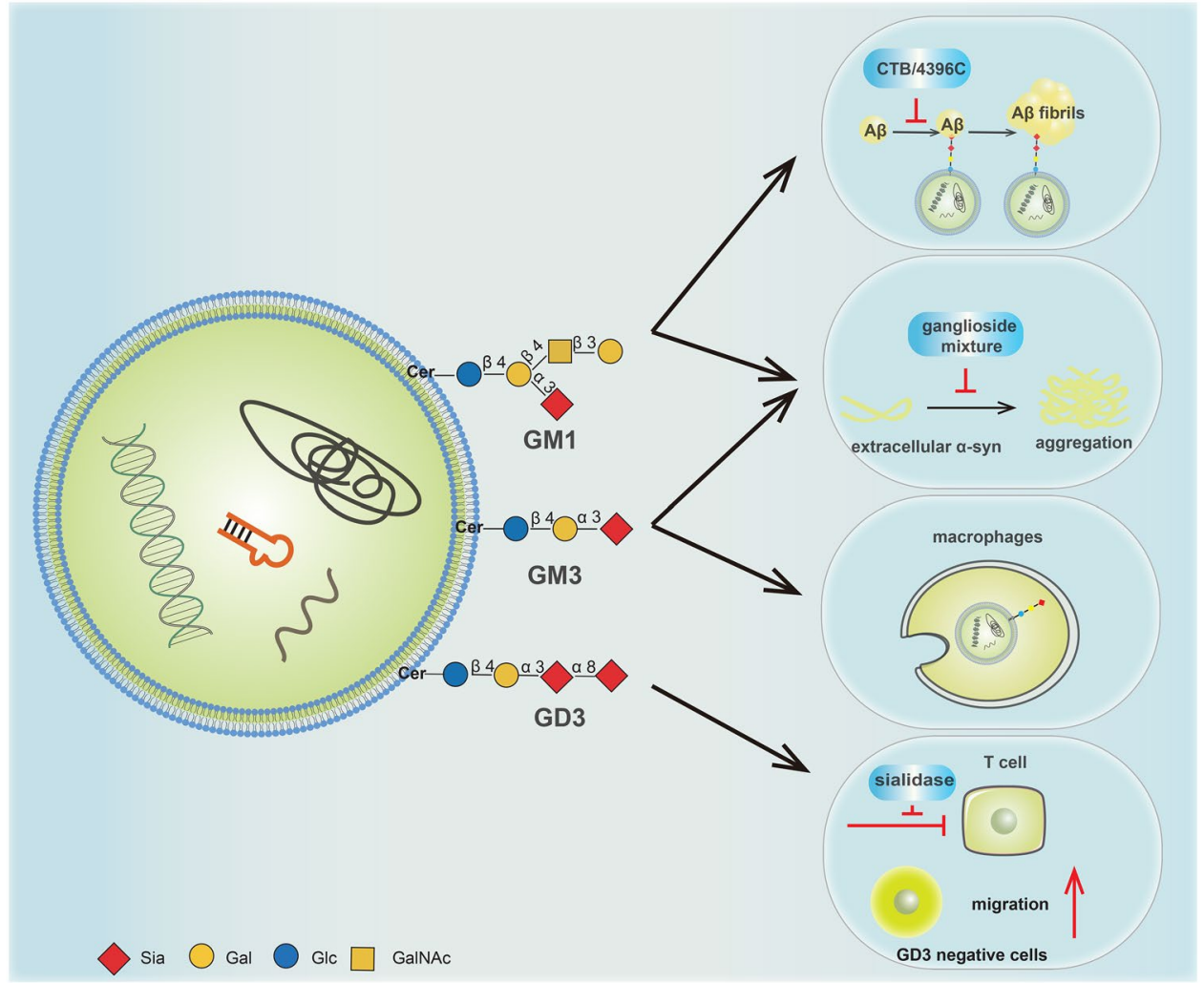


endowed with negative charge. When they released in a low $\mathrm{pH}$ condition, sEVs were positively charged and fused better with cells [78]. The fusion efficiency of sEVs is higher in metastasis tumors than in primary tumors, thus the enrichment of GM3 on sEVs may become a key factor to affect the tumorigenesis. On the other hand, at a low $\mathrm{pH}$ condition, the rate of $\alpha$-syn aggregation increases dramatically $[79,80]$. These findings provide new insights into possible mechanisms of GM3 in PD. In addition, GM3 plays a crucial role in enveloped virus entry and trafficking. GM3 binds to macrophages and dendritic cells by recognizing CD169 (also termed Siglec1) [81-83]. The GM3-CD169 recognition could drive virus to transmit to $\mathrm{T}$ cell targets through macrophages and dendritic cells [84]. The GM3-CD169 interaction could also accumulate exogenous virus particles in intracellular compartments, which are the virus-containing compartments and considered an ideal reservoir for the virus to evade the host's immune system [85]. Therefore, GM3-presenting artificial virus nanoparticles can be used as a platform for delivering antiretroviral drugs to intracellular compartments to selectively targeting virus. Furthermore, it was reported that the GM3-enriched SEVs were positively correlated with the severity of COVID-19 patients [13].

Another ganglioside on sEVs, GD3, has been reported to be associated with multiple cancers and contributed to immunosuppression [86, 87]. When normal melanocyte cells were transfected with GD3 synthase gene (ST8Sia I), melanocytes shed their sEVs enriched in GD3. The sEVs further partition into recipient cells and modify the behavior of normal cells. And the sEVs produced by GD3 overexpressing cells was able to stimulate cell migration in parental melanocytes [88]. In addition, GD3 on sEVs is also associated with immunosuppression and functional arrest of $\mathrm{T}$ cells. Several studies have shown that GD3 induces apoptosis of T cells, and high levels of GD3 could inhibit NKT cell activation in ovarian cancer $[89,90]$. Study also revealed that GD3 directly inhibits $\mathrm{T}$ cells activation, rather than other cargos in sEVs [12]. This inhibition could be impaired by antibody blockade of GD3 or sialidase treatment, indicating that both GD3 and sialic acid on sEVs represent potential to be therapeutic targets for enhancing the antitumor activity of $\mathrm{T}$ cells in ovarian cancer [12].

\section{Perspective}

This review introduced the background of GSLs, and focuses on the function of GSLs on sEVs. sEVs are believed to play crucial roles in a wide range of biological processes and contain several bioactive molecules, including lipids, proteins and nucleic acids. However, the study of functional roles of GSLs on SEVs are far behind than other functional cargos. It is fairly crucial that new technologies and methods for isolation and characterization of GSLs on sEVs should be developed and improved. More researches are needed to clarify the relationship between GSLs on sEVs and disease with an aim to find potential therapeutic targets.

Funding This work was supported by the National Science Foundation of China (No. 31971211, 82172828), Science Foundation for Distinguished Young Scholars of Shaanxi Province (2021 J-C39), the Natural Science Foundation of Shaanxi. Province (2019JZ-22) and the Youth Innovation Team of Shaanxi Universities.

\section{Declarations}

Ethical approval This article does not contain any studies with human participants or animals performed by any of the authors.

Competing interests The authors have no competing interests to declare that are relevant to the content of this article.

\section{References}

1. El Andaloussi, S., Mager, I., Breakefield, X.O., Wood, M.J.: Extracellular vesicles: biology and emerging therapeutic opportunities. Nat. Rev. Drug Discov. 12(5), 347-357 (2013). https://doi.org/10.1038/nrd3978

2. Xu, R., Rai, A., Chen, M., Suwakulsiri, W., Greening, D.W., Simpson, R.J.: Extracellular vesicles in cancer - implications for future improvements in cancer care. Nat. Rev. Clin. Oncol. 15(10), 617-638 (2018). https://doi.org/10.1038/s41571-018-0036-9

3. Becker, A., Thakur, B.K., Weiss, J.M., Kim, H.S., Peinado, H., Lyden, D.: Extracellular Vesicles in Cancer: Cell-to-Cell Mediators of Metastasis. Cancer Cell 30(6), 836-848 (2016). https://doi. org/10.1016/j.ccell.2016.10.009

4. Huang, T., Song, C., Zheng, L., Xia, L., Li, Y., Zhou, Y.: The roles of extracellular vesicles in gastric cancer development, microenvironment, anti-cancer drug resistance, and therapy. Mol. Cancer 18(1), 62 (2019). https://doi.org/10.1186/s12943-019-0967-5

5. Costa, J.: Glycoconjugates from extracellular vesicles: Structures, functions and emerging potential as cancer biomarkers. Biochim. Biophys. Acta. Rev. Cancer 1868(1), 157-166 (2017). https://doi. org/10.1016/j.bbcan.2017.03.007

6. Pinho, S.S., Reis, C.A.: Glycosylation in cancer: mechanisms and clinical implications. Nat. Rev. Cancer 15(9), 540-555 (2015). https://doi.org/10.1038/nrc3982

7. Tan, Z., Cao, L., Wu, Y., Wang, B., Song, Z., Yang, J., Cheng, L., Yang, X., Zhou, X., Dai, Z., Li, X., Guan, F.: Bisecting GlcNAc modification diminishes the pro-metastatic functions of small extracellular vesicles from breast cancer cells. J. Extracell. Vesicles 10(1), e12005 (2020). https://doi.org/10.1002/jev2.12005

8. Harada, Y., Kizuka, Y., Tokoro, Y., Kondo, K., Yagi, H., Kato, K., Inoue, H., Taniguchi, N., Maruyama, I.: N-glycome inheritance from cells to extracellular vesicles in B16 melanomas. FEBS Lett. 593(9), 942-951 (2019). https://doi.org/10.1002/1873-3468.13377

9. Yamamoto, M., Harada, Y., Suzuki, T., Fukushige, T., Yamakuchi, M., Kanekura, T., Dohmae, N., Hori, K., Maruyama, I.: Application of high-mannose-type glycan-specific lectin from Oscillatoria Agardhii for affinity isolation of tumor-derived extracellular vesicles. Anal. Biochem. 580, 21-29 (2019). https://doi.org/10.1016/j. ab.2019.06.001

10. Yokose, T., Kabe, Y., Matsuda, A., Kitago, M., Matsuda, S., Hirai, M., Nakagawa, T., Masugi, Y., Hishiki, T., Nakamura, Y., 
Shinoda, M., Yagi, H., Abe, Y., Oshima, G., Hori, S., Nakano, Y., Honda, K., Kashiro, A., Morizane, C., Nara, S., Kikuchi, S., Shibahara, T., Itonaga, M., Ono, M., Minegishi, N., Koshiba, S., Yamamoto, M., Kuno, A., Handa, H., Sakamoto, M., Suematsu, M., Kitagawa, Y.: O-Glycan-Altered Extracellular Vesicles: A Specific Serum Marker Elevated in Pancreatic Cancer. Cancers (Basel) 12(9) (2020). https://doi.org/10.3390/cancers 12092469

11. Schnaar, R.L., Kinoshita, T.: Glycosphingolipids. In: rd, Varki, A., Cummings, R.D., Esko, J.D., Stanley, P., Hart, G.W., Aebi, M., Darvill, A.G., Kinoshita, T., Packer, N.H., Prestegard, J.H., Schnaar, R.L., Seeberger, P.H. (eds.) Essentials of Glycobiology. pp. 125-135. Cold Spring Harbor (NY) (2015)

12. Shenoy, G.N., Loyall, J., Berenson, C.S., Kelleher, R.J., Jr., Iyer, V., Balu-Iyer, S.V., Odunsi, K., Bankert, R.B.: Sialic AcidDependent Inhibition of T Cells by Exosomal Ganglioside GD3 in Ovarian Tumor Microenvironments. J. Immunol. 201(12), 3750-3758 (2018). https://doi.org/10.4049/jimmunol.1801041

13. Song, J.W., Lam, S.M., Fan, X., Cao, W.J., Wang, S.Y., Tian, H., Chua, G.H., Zhang, C., Meng, F.P., Xu, Z., Fu, J.L., Huang, L., Xia, P., Yang, T., Zhang, S., Li, B., Jiang, T.J., Wang, R., Wang, Z., Shi, M., Zhang, J.Y., Wang, F.S., Shui, G.: Omics-Driven Systems Interrogation of Metabolic Dysregulation in COVID-19 Pathogenesis. Cell Metab. 32(2), 188-202 e185 (2020). https:// doi.org/10.1016/j.cmet.2020.06.016

14. Yuyama, K., Yamamoto, N., Yanagisawa, K.: Accelerated release of exosome-associated GM1 ganglioside (GM1) by endocytic pathway abnormality: another putative pathway for GM1-induced amyloid fibril formation. J. Neurochem. 105(1), 217-224 (2008). https://doi.org/10.1111/j.1471-4159.2007.05128.x

15. Hakomori, S.I.: Structure and function of glycosphingolipids and sphingolipids: recollections and future trends. Biochim. Biophys. Acta. 1780(3), 325-346 (2008). https://doi.org/10.1016/j.bbagen. 2007.08.015

16. Zhang, T., de Waard, A.A., Wuhrer, M., Spaapen, R.M.: The Role of Glycosphingolipids in Immune Cell Functions. Front. Immunol. 10, 90 (2019). https://doi.org/10.3389/fimmu.2019.00090

17. Hakomori, S.: Structure, organization, and function of glycosphingolipids in membrane. Curr. Opin. Hematol. 10(1), 16-24 (2003). https://doi.org/10.1097/00062752-200301000-00004

18. Hakomori, S.I., Handa, K.J.S.J.: Regulation of Growth Factor Receptors by Glycosphingolipids. (2016)

19. Hakomori, S.I.: Glycosynaptic microdomains controlling tumor cell phenotype through alteration of cell growth, adhesion, and motility. FEBS Lett. 584(9), 1901-1906 (2010). https://doi.org/ 10.1016/j.febslet.2009.10.065

20. Hakomori, S.I., Handa, K.: GM3 and cancer. Glycoconj. J. 32(1-2), 1-8 (2015). https://doi.org/10.1007/s10719-014-9572-4

21. Yoon, S.J., Nakayama, K., Takahashi, N., Yagi, H., Utkina, N., Wang, H.Y., Kato, K., Sadilek, M., Hakomori, S.I.: Interaction of $\mathrm{N}$-linked glycans, having multivalent GlcNAc termini, with GM3 ganglioside. Glycoconj. J. 23(9), 639-649 (2006). https://doi.org/ 10.1007/s10719-006-9001-4

22. Miljan, E.A., Meuillet, E.J., Mania-Farnell, B., George, D., Yamamoto, H., Simon, H.G., Bremer, E.G.: Interaction of the extracellular domain of the epidermal growth factor receptor with gangliosides. J. Biol. Chem. 277(12), 10108-10113 (2002). https://doi.org/10.1074/jbc.M111669200

23. Toledo, M.S., Suzuki, E., Handa, K., Hakomori, S.: Cell growth regulation through GM3-enriched microdomain (glycosynapse) in human lung embryonal fibroblast WI38 and its oncogenic transformant VA13. J. Biol. Chem. 279(33), 34655-34664 (2004). https://doi.org/10.1074/jbc.M403857200

24. Yates, A.J., VanBrocklyn, J., Saqr, H.E., Guan, Z., Stokes, B.T., O'Dorisio, M.S.: Mechanisms through which gangliosides inhibit PDGF-stimulated mitogenesis in intact Swiss 3T3 cells: receptor tyrosine phosphorylation, intracellular calcium, and receptor binding.
Exp. Cell Res. 204(1), 38-45 (1993). https://doi.org/10.1006/excr. 1993.1006

25. Hakomori, S.: Carbohydrate-to-carbohydrate interaction, through glycosynapse, as a basis of cell recognition and membrane organization. Glycoconj. J. 21(3-4), 125-137 (2004). https://doi.org/10. 1023/B:GLYC.0000044844.95878.cf

26. Lakshminarayan, R., Wunder, C., Becken, U., Howes, M.T., Benzing, C., Arumugam, S., Sales, S., Ariotti, N., Chambon, V., Lamaze, C., Loew, D., Shevchenko, A., Gaus, K., Parton, R.G., Johannes, L.: Galectin-3 drives glycosphingolipid-dependent biogenesis of clathrin-independent carriers. Nat. Cell Biol. 16(6), 595-606 (2014). https://doi.org/10.1038/ncb2970

27. Ochieng, J., Leite-Browning, M.L., Warfield, P.: Regulation of cellular adhesion to extracellular matrix proteins by galectin-3. Biochem. Biophys. Res. Commun. 246(3), 788-791 (1998). https://doi.org/10.1006/bbrc.1998.8708

28. Stroud, M.R., Handa, K., Ito, K., Salyan, M.E., Fang, H., Levery, S.B., Hakamori, S., Reinhold, B.B., Reinhold, V.N.: Myeloglycan, a series of E-selectin-binding polylactosaminolipids found in normal human leukocytes and myelocytic leukemia HL60 cells. Biochem. Biophys. Res. Commun. 209(3), 777-787 (1995). https:// doi.org/10.1006/bbrc.1995.1568

29. Nimrichter, L., Burdick, M.M., Aoki, K., Laroy, W., Fierro, M.A., Hudson, S.A., Von Seggern, C.E., Cotter, R.J., Bochner, B.S., Tiemeyer, M., Konstantopoulos, K., Schnaar, R.L.: E-selectin receptors on human leukocytes. Blood 112(9), 3744-3752 (2008). https://doi.org/10.1182/blood-2008-04-149641

30. Regina Todeschini, A., Hakomori, S.I.: Functional role of glycosphingolipids and gangliosides in control of cell adhesion, motility, and growth, through glycosynaptic microdomains. Biochim. Biophys. Acta. 1780(3), 421-433 (2008). https://doi.org/ 10.1016/j.bbagen.2007.10.008

31. Hakomori Si, S.I.: The glycosynapse. Proc. Natl. Acad. Sci. USA 99(1), 225-232 (2002). https://doi.org/10.1073/pnas.012540899

32. Ono, M., Handa, K., Sonnino, S., Withers, D.A., Nagai, H., Hakomori, S.: GM3 ganglioside inhibits CD9-facilitated haptotactic cell motility: coexpression of GM3 and CD9 is essential in the downregulation of tumor cell motility and malignancy. Biochemistry 40(21), 6414-6421 (2001). https://doi.org/10.1021/bi0101998

33. Kawakami, Y., Kawakami, K., Steelant, W.F., Ono, M., Baek, R.C., Handa, K., Withers, D.A., Hakomori, S.: Tetraspanin CD9 is a "proteolipid," and its interaction with alpha 3 integrin in microdomain is promoted by GM3 ganglioside, leading to inhibition of laminin-5-dependent cell motility. J. Biol. Chem. 277(37), 34349-34358 (2002). https://doi.org/10.1074/jbc.M200771200

34. Miura, Y., Kainuma, M., Jiang, H., Velasco, H., Vogt, P.K., Hakomori, S.: Reversion of the Jun-induced oncogenic phenotype by enhanced synthesis of sialosyllactosylceramide (GM3 ganglioside). Proc. Natl. Acad. Sci. USA 101(46), 16204-16209 (2004). https://doi.org/10. 1073/pnas.0407297101

35. Todeschini, A.R., Dos Santos, J.N., Handa, K., Hakomori, S.I.: Ganglioside GM2-tetraspanin CD82 complex inhibits met and its cross-talk with integrins, providing a basis for control of cell motility through glycosynapse. J. Biol. Chem. 282(11), 81238133 (2007). https://doi.org/10.1074/jbc.M611407200

36. Jennemann, R., Volz, M., Bestvater, F., Schmidt, C., Richter, K., Kaden, S., Muthing, J., Grone, H.J., Sandhoff, R.: Blockade of Glycosphingolipid Synthesis Inhibits Cell Cycle and Spheroid Growth of Colon Cancer Cells In Vitro and Experimental Colon Cancer Incidence In Vivo. Int. J. Mol. Sci. 22(19) (2021). https:// doi.org/10.3390/ijms221910539

37. Kovbasnjuk, O., Mourtazina, R., Baibakov, B., Wang, T., Elowsky, C., Choti, M.A., Kane, A., Donowitz, M.: The glycosphingolipid globotriaosylceramide in the metastatic transformation of colon cancer. Proc. Natl. Acad. Sci. USA 102(52), 19087-19092 (2005). https://doi.org/10.1073/pnas.0506474102 
38. Park, S.Y., Kwak, C.Y., Shayman, J.A., Kim, J.H.: Globoside promotes activation of ERK by interaction with the epidermal growth factor receptor. Biochim. Biophys. Acta. 1820(7), 1141-1148 (2012). https://doi.org/10.1016/j.bbagen.2012.04.008

39. Suzuki, Y., Haraguchi, N., Takahashi, H., Uemura, M., Nishimura, J., Hata, T., Takemasa, I., Mizushima, T., Ishii, H., Doki, Y., Mori, M., Yamamoto, H.: SSEA-3 as a novel amplifying cancer cell surface marker in colorectal cancers. Int. J. Oncol. 42(1), 161-167 (2013). https://doi.org/10.3892/ijo.2012.1713

40. Kwak, D.H., Ryu, J.S., Kim, C.H., Ko, K., Ma, J.Y., Hwang, K.A., Choo, Y.K.: Relationship between ganglioside expression and anti-cancer effects of the monoclonal antibody against epithelial cell adhesion molecule in colon cancer. Exp. Mol. Med. 43(12), 693-701 (2011). https://doi.org/10.3858/emm.2011.43.12.080

41. Chuang, P.K., Hsiao, M., Hsu, T.L., Chang, C.F., Wu, C.Y., Chen, B.R., Huang, H.W., Liao, K.S., Chen, C.C., Chen, C.L., Yang, S.M., Kuo, C.W., Chen, P., Chiu, P.T., Chen, I.J., Lai, J.S., Yu, C.T., Wong, C.H.: Signaling pathway of globo-series glycosphingolipids and beta1,3-galactosyltransferase V (beta3GalT5) in breast cancer. Proc. Natl. Acad. Sci. USA 116(9), 3518-3523 (2019). https://doi.org/10.1073/pnas.1816946116

42. Sarkar, T.R., Battula, V.L., Werden, S.J., Vijay, G.V., Ramirez-Pena, E.Q., Taube, J.H., Chang, J.T., Miura, N., Porter, W., Sphyris, N., Andreeff, M., Mani, S.A.: GD3 synthase regulates epithelialmesenchymal transition and metastasis in breast cancer. Oncogene 34(23), 2958-2967 (2015). https://doi.org/10.1038/onc.2014.245

43. Marijan, S., Markotic, A., Mastelic, A., Rezic-Muzinic, N., Pilkington, L.I., Reynisson, J., Culic, V.C.: Glycosphingolipid expression at breast cancer stem cells after novel thieno[2,3-b]pyridine anticancer compound treatment. Sci. Rep. 10(1), 11876 (2020). https://doi.org/ 10.1038/s41598-020-68516-y

44. Wang, Z., Wen, L., Ma, X., Chen, Z., Yu, Y., Zhu, J., Wang, Y., Liu, Z., Liu, H., Wu, D., Zhou, D., Li, Y.: High expression of lactotriaosylceramide, a differentiation-associated glycosphingolipid, in the bone marrow of acute myeloid leukemia patients. Glycobiology 22(7), 930-938 (2012). https://doi.org/10.1093/glycob/cws061

45. Groux-Degroote, S., Delannoy, P.: Cancer-Associated Glycosphingolipids as Tumor Markers and Targets for Cancer Immunotherapy. Int. J. Mol. Sci. 22(11) (2021). https://doi.org/10.3390/ijms22116145

46. Yu, J., Hung, J.T., Wang, S.H., Cheng, J.Y., Yu, A.L.: Targeting glycosphingolipids for cancer immunotherapy. FEBS Lett. 594(22), 3602-3618 (2020). https://doi.org/10.1002/1873-3468.13917

47. Hallett, P.J., Huebecker, M., Brekk, O.R., Moloney, E.B., Rocha, E.M., Priestman, D.A., Platt, F.M., Isacson, O.: Glycosphingolipid levels and glucocerebrosidase activity are altered in normal aging of the mouse brain. Neurobiol. Aging 67, 189-200 (2018). https:// doi.org/10.1016/j.neurobiolaging.2018.02.028

48. Bernardo, A., Harrison, F.E., McCord, M., Zhao, J., Bruchey, A., Davies, S.S., Jackson Roberts, L., 2nd, Mathews, P.M., Matsuoka, Y., Ariga, T., Yu, R.K., Thompson, R., McDonald, M.P.: Elimination of GD3 synthase improves memory and reduces amyloid-beta plaque load in transgenic mice. Neurobiol. Aging 30(11), 1777-1791 (2009). https://doi.org/10.1016/j.neurobiolaging.2007.12.022

49. Oikawa, N., Yamaguchi, H., Ogino, K., Taki, T., Yuyama, K., Yamamoto, N., Shin, R.W., Furukawa, K., Yanagisawa, K.: Gangliosides determine the amyloid pathology of Alzheimer's disease. NeuroReport 20(12), 1043-1046 (2009). https://doi.org/10.1097/ WNR.0b013e32832e4b9d

50. Yanagisawa, K., Odaka, A., Suzuki, N., Ihara, Y.: GM1 gangliosidebound amyloid beta-protein (A beta): a possible form of preamyloid in Alzheimer's disease. Nat. Med. 1(10), 1062-1066 (1995). https:// doi.org/10.1038/nm1095-1062

51. Matsuzaki, K., Kato, K., Yanagisawa, K.: Ganglioside-Mediated Assembly of Amyloid beta-Protein: Roles in Alzheimer's Disease. Prog. Mol. Biol. Transl. Sci. 156, 413-434 (2018). https://doi.org/ 10.1016/bs.pmbts.2017.10.005
52. Kreutz, F., Frozza, R.L., Breier, A.C., de Oliveira, V.A., Horn, A.P., Pettenuzzo, L.F., Netto, C.A., Salbego, C.G., Trindade, V.M.: Amyloid-beta induced toxicity involves ganglioside expression and is sensitive to GM1 neuroprotective action. Neurochem. Int. 59(5), 648-655 (2011). https://doi.org/10.1016/j.neuint.2011. 06.007

53. Amaro, M., Sachl, R., Aydogan, G., Mikhalyov, I.I., Vacha, R., Hof, M.: GM1 Ganglioside Inhibits beta-Amyloid Oligomerization Induced by Sphingomyelin. Angew. Chem. Int. Ed. Engl. 55(32), 9411-9415 (2016). https://doi.org/10.1002/ anie. 201603178

54. Kreutz, F., Scherer, E.B., Ferreira, A.G., Petry Fdos, S., Pereira, C.L., Santana, F., de Souza Wyse, A.T., Salbego, C.G., Trindade, V.M.: Alterations on $\mathrm{Na}(+), \mathrm{K}(+)$-ATPase and acetylcholinesterase activities induced by amyloid-beta peptide in rat brain and GM1 ganglioside neuroprotective action. Neurochem. Res. 38(11), 2342-2350 (2013). https://doi.org/10.1007/s11064-013-1145-6

55. Huang, M., Hu, M., Song, Q., Song, H., Huang, J., Gu, X., Wang, X., Chen, J., Kang, T., Feng, X., Jiang, D., Zheng, G., Chen, H., Gao, X.: GM1-Modified Lipoprotein-like Nanoparticle: Multifunctional Nanoplatform for the Combination Therapy of Alzheimer's Disease. ACS Nano 9(11), 10801-10816 (2015). https://doi. org/10.1021/acsnano.5b03124

56. Hu, T., Zhang, J.L.: Mass-spectrometry-based lipidomics. J. Sep. Sci. 41(1), 351-372 (2018). https://doi.org/10.1002/jssc.201700709

57. Llorente, A., Skotland, T., Sylvanne, T., Kauhanen, D., Rog, T., Orlowski, A., Vattulainen, I., Ekroos, K., Sandvig, K.: Molecular lipidomics of exosomes released by PC-3 prostate cancer cells. Biochim. Biophys. Acta 1831(7), 1302-1309 (2013). https://doi. org/10.1016/j.bbalip.2013.04.011

58. Engel, K.M., Schiller, J.: A comparison of PC oxidation products as detected by MALDI-TOF and ESI-IT mass spectrometry. Chem. Phys. Lipids 203, 33-45 (2017). https://doi.org/10.1016/j. chemphyslip.2016.12.007

59. Wubbolts, R., Leckie, R.S., Veenhuizen, P.T., Schwarzmann, G., Mobius, W., Hoernschemeyer, J., Slot, J.W., Geuze, H.J., Stoorvogel, W.: Proteomic and biochemical analyses of human B cell-derived exosomes. Potential implications for their function and multivesicular body formation. J. Biol. Chem. 278(13), 10963-10972 (2003). https://doi.org/10.1074/jbc.M207550200

60. Das, A., Barrientos, R., Shiota, T., Madigan, V., Misumi, I., McKnight, K.L., Sun, L., Li, Z., Meganck, R.M., Li, Y., Kaluzna, E., Asokan, A., Whitmire, J.K., Kapustina, M., Zhang, Q., Lemon, S.M.: Gangliosides are essential endosomal receptors for quasi-enveloped and naked hepatitis A virus. Nat. Microbiol. 5(9), 1069-1078 (2020). https://doi.org/ 10.1038/s41564-020-0727-8

61. Desplantes, R., Leveque, C., Muller, B., Lotierzo, M., Ferracci, G., Popoff, M., Seagar, M., Mamoun, R., El Far, O.: Affinity biosensors using recombinant native membrane proteins displayed on exosomes: application to botulinum neurotoxin B receptor. Sci. Rep. 7(1), 1032 (2017). https://doi.org/10.1038/ s41598-017-01198-1

62. Picciolini, S., Gualerzi, A., Vanna, R., Sguassero, A., Gramatica, F., Bedoni, M., Masserini, M., Morasso, C.: Detection and Characterization of Different Brain-Derived Subpopulations of Plasma Exosomes by Surface Plasmon Resonance Imaging. Anal. Chem. 90(15), 8873-8880 (2018). https://doi.org/10.1021/acs.analchem. $8 \mathrm{~b} 00941$

63. Sapon, K., Maziarz, D., Janas, T., Sikorski, A.F., Janas, T.: Cholera Toxin Subunit B for Sensitive and Rapid Determination of Exosomes by Gel Filtration. Membranes (Basel) 10(8) (2020). https://doi.org/ 10.3390/membranes 10080172

64. Tan, S.S., Yin, Y., Lee, T., Lai, R.C., Yeo, R.W., Zhang, B., Choo, A., Lim, S.K.: Therapeutic MSC exosomes are derived from lipid raft microdomains in the plasma membrane. J. Extracell. Vesicles 2 (2013). https://doi.org/10.3402/jev.v2i0.22614 
65. Marimpietri, D., Petretto, A., Raffaghello, L., Pezzolo, A., Gagliani, C., Tacchetti, C., Mauri, P., Melioli, G., Pistoia, V.: Proteome profiling of neuroblastoma-derived exosomes reveal the expression of proteins potentially involved in tumor progression. PLoS One 8(9), e75054 (2013). https://doi.org/10.1371/journal.pone.0075054

66. Keerthikumar, S., Chisanga, D., Ariyaratne, D., Al Saffar, H., Anand, S., Zhao, K., Samuel, M., Pathan, M., Jois, M., Chilamkurti, N., Gangoda, L., Mathivanan, S.: ExoCarta: A Web-Based Compendium of Exosomal Cargo. J. Mol. Biol. 428(4), 688-692 (2016). https://doi. org/10.1016/j.jmb.2015.09.019

67. de Gassart, A., Geminard, C., Fevrier, B., Raposo, G., Vidal, M.: Lipid raft-associated protein sorting in exosomes. Blood 102(13), 4336-4344 (2003). https://doi.org/10.1182/blood-2003-03-0871

68. Grey, M., Dunning, C.J., Gaspar, R., Grey, C., Brundin, P., Sparr, E., Linse, S.: Acceleration of alpha-synuclein aggregation by exosomes. J. Biol. Chem. 290(5), 2969-2982 (2015). https://doi. org/10.1074/jbc.M114.585703

69. Atik, A., Stewart, T., Zhang, J.: Alpha-Synuclein as a Biomarker for Parkinson's Disease. Brain Pathol. 26(3), 410-418 (2016). https://doi.org/10.1111/bpa.12370

70. Badawy, S.M.M., Okada, T., Kajimoto, T., Hirase, M., Matovelo, S.A., Nakamura, S., Yoshida, D., Ijuin, T., Nakamura, S.I.: Extracellular alpha-synuclein drives sphingosine 1-phosphate receptor subtype 1 out of lipid rafts, leading to impaired inhibitory G-protein signaling. J. Biol. Chem. 293(21), 8208-8216 (2018). https://doi.org/10.1074/jbc.RA118.001986

71. Dai, Y., Zhang, M., Shi, X., Wang, K., Gao, G., Shen, L., Sun, T.: Kinetic study of Abeta(1-42) amyloidosis in the presence of ganglioside-containing vesicles. Colloids Surf B Biointerfaces 185, 110615 (2020). https://doi.org/10.1016/j.colsurfb.2019.110615

72. Hayashi, H., Kimura, N., Yamaguchi, H., Hasegawa, K., Yokoseki, T., Shibata, M., Yamamoto, N., Michikawa, M., Yoshikawa, Y., Terao, K., Matsuzaki, K., Lemere, C.A., Selkoe, D.J., Naiki, H., Yanagisawa, K.: A seed for Alzheimer amyloid in the brain. J. Neurosci. 24(20), 4894-4902 (2004). https://doi.org/10.1523/ JNEUROSCI.0861-04.2004

73. Yuyama, K., Sun, H., Mitsutake, S., Igarashi, Y.: Sphingolipidmodulated exosome secretion promotes clearance of amyloidbeta by microglia. J. Biol. Chem. 287(14), 10977-10989 (2012). https://doi.org/10.1074/jbc.M111.324616

74. Fiandaca, M.S., Kapogiannis, D., Mapstone, M., Boxer, A., Eitan, E., Schwartz, J.B., Abner, E.L., Petersen, R.C., Federoff, H.J., Miller, B.L., Goetzl, E.J.: Identification of preclinical Alzheimer's disease by a profile of pathogenic proteins in neurally derived blood exosomes: A case-control study. Alzheimers Dement 11(6), 600-607 e601 (2015). https://doi.org/10.1016/j.jalz.2014.06.008

75. Shi, M., Liu, C., Cook, T.J., Bullock, K.M., Zhao, Y., Ginghina, C., Li, Y., Aro, P., Dator, R., He, C., Hipp, M.J., Zabetian, C.P., Peskind, E.R., Hu, S.C., Quinn, J.F., Galasko, D.R., Banks, W.A., Zhang, J.: Plasma exosomal alpha-synuclein is likely CNS-derived and increased in Parkinson's disease. Acta. Neuropathol. 128(5), 639-650 (2014). https://doi.org/10.1007/s00401-014-1314-y

76. Pace, K.R., Dutt, R., Galileo, D.S.: Exosomal L1CAM Stimulates Glioblastoma Cell Motility, Proliferation, and Invasiveness. Int. J. Mol. Sci. 20(16) (2019). https://doi.org/10.3390/ijms20163982

77. Rohani, N., Hao, L., Alexis, M.S., Joughin, B.A., Krismer, K., Moufarrej, M.N., Soltis, A.R., Lauffenburger, D.A., Yaffe, M.B., Burge, C.B., Bhatia, S.N., Gertler, F.B.: Acidification of Tumor at Stromal Boundaries Drives Transcriptome Alterations Associated with Aggressive Phenotypes. Cancer Res. 79(8), 1952-1966 (2019). https://doi.org/10.1158/0008-5472.CAN-18-1604

78. Parolini, I., Federici, C., Raggi, C., Lugini, L., Palleschi, S., De Milito, A., Coscia, C., Iessi, E., Logozzi, M., Molinari, A., Colone, M., Tatti, M., Sargiacomo, M., Fais, S.: Microenvironmental pH is a key factor for exosome traffic in tumor cells. J. Biol. Chem. 284(49), 34211-34222 (2009). https://doi.org/10.1074/jbc.M109. 041152

79. Peduzzo, A., Linse, S., Buell, A.K.: The Properties of alphaSynuclein Secondary Nuclei Are Dominated by the Solution Conditions Rather than the Seed Fibril Strain. ACS Chem. Neurosci. 11(6), 909-918 (2020). https://doi.org/10.1021/ acschemneuro.9b00594

80. Buell, A.K., Galvagnion, C., Gaspar, R., Sparr, E., Vendruscolo, M., Knowles, T.P., Linse, S., Dobson, C.M.: Solution conditions determine the relative importance of nucleation and growth processes in alpha-synuclein aggregation. Proc. Natl. Acad. Sci. USA 111(21), 7671-7676 (2014). https://doi.org/10.1073/pnas.1315346111

81. Izquierdo-Useros, N., Lorizate, M., McLaren, P.J., Telenti, A., Krausslich, H.G., Martinez-Picado, J.: HIV-1 capture and transmission by dendritic cells: the role of viral glycolipids and the cellular receptor Siglec-1. PLoS Pathog. 10(7), e1004146 (2014). https://doi.org/10.1371/journal.ppat.1004146

82. Puryear, W.B., Yu, X., Ramirez, N.P., Reinhard, B.M., Gummuluru, S.: HIV-1 incorporation of host-cell-derived glycosphingolipid GM3 allows for capture by mature dendritic cells. Proc. Natl. Acad. Sci. USA 109(19), 7475-7480 (2012). https://doi.org/10.1073/pnas.1201104109

83. Puryear, W.B., Akiyama, H., Geer, S.D., Ramirez, N.P., Yu, X., Reinhard, B.M., Gummuluru, S.: Interferon-inducible mechanism of dendritic cell-mediated HIV-1 dissemination is dependent on Siglec-1/CD169. PLoS Pathog. 9(4), e1003291 (2013). https:// doi.org/10.1371/journal.ppat.1003291

84. Kijewski, S.D., Gummuluru, S.: A mechanistic overview of dendritic cell-mediated HIV-1 trans infection: the story so far. Future Virol. 10(3), 257-269 (2015). https://doi.org/10.2217/fvl.15.2

85. Xu, F., Bandara, A., Akiyama, H., Eshaghi, B., Stelter, D., Keyes, T., Straub, J.E., Gummuluru, S., Reinhard, B.M.: Membranewrapped nanoparticles probe divergent roles of GM3 and phosphatidylserine in lipid-mediated viral entry pathways. Proc. Natl. Acad. Sci. USA 115(39), E9041-E9050 (2018). https://doi.org/ 10.1073/pnas.1804292115

86. Del Boccio, P., Raimondo, F., Pieragostino, D., Morosi, L., Cozzi, G., Sacchetta, P., Magni, F., Pitto, M., Urbani, A.: A hyphenated microLC-Q-TOF-MS platform for exosomal lipidomics investigations: application to RCC urinary exosomes. Electrophoresis 33(4), 689-696 (2012). https://doi.org/10.1002/elps.201100375

87. Biswas, S., Biswas, K., Richmond, A., Ko, J., Ghosh, S., Simmons, M., Rayman, P., Rini, B., Gill, I., Tannenbaum, C.S., Finke, J.H.: Elevated levels of select gangliosides in T cells from renal cell carcinoma patients is associated with T cell dysfunction. J. Immunol. 183(8), 5050-5058 (2009). https://doi.org/10.4049/jimmunol.0900259

88. Otake, A.H., de Freitas Saito, R., Duarte, A.P.M., Ramos, A.F., Chammas, R.: GD3 ganglioside-enriched extracellular vesicles stimulate melanocyte migration. Biochim. Biophys. Acta. Mol. Cell Biol. Lipids 1864(3), 422-432 (2019). https://doi.org/10. 1016/j.bbalip.2018.06.014

89. Sa, G., Das, T., Moon, C., Hilston, C.M., Rayman, P.A., Rini, B.I., Tannenbaum, C.S., Finke, J.H.: GD3, an overexpressed tumorderived ganglioside, mediates the apoptosis of activated but not resting T cells. Cancer Res. 69(7), 3095-3104 (2009). https://doi. org/10.1158/0008-5472.CAN-08-3776

90. Webb, T.J., Li, X., Giuntoli, R.L., 2nd., Lopez, P.H., Heuser, C., Schnaar, R.L., Tsuji, M., Kurts, C., Oelke, M., Schneck, J.P.: Molecular identification of GD3 as a suppressor of the innate immune response in ovarian cancer. Cancer Res. 72(15), 37443752 (2012). https://doi.org/10.1158/0008-5472.CAN-11-2695

Publisher's Note Springer Nature remains neutral with regard to jurisdictional claims in published maps and institutional affiliations. 